MILAN RADOVANOVIĆ, PhD, Historian

Belgrade, Republic of Serbia

mradowanovic@gmail.com

originalan naučni rad

UDK: $314.151 .3-054.72(=411.16)(569.4) " 1948 / 1952 "$

primljeno: 27. april 2018.

323.13:314(=411.16)(497.1)"1948/1952"

prihvaćeno: 10. oktobar 2018.

https://doi.org/10.29362/ist20veka.2019.1.rad.121-138

\title{
THE INTERNAL FRAMEWORK OF ORGANIZED JEWISH MIGRATION FROM YUGOSLAVIA TO ISRAEL (1948-1952)
}

\begin{abstract}
In preparing for mass Jewish emigration to Israel, executives of the Federation of Jewish religious communities of Yugoslavia decided on defining a specific structure within the community to deal with two basic tasks - communicating information relevant to the migration to all of the participating sides and dealing with problems potentially arising from the process. While top to bottom communication followed this model for the most part, passing information in the opposite direction proved to be much more of a challenge. Traditional dynamics of the Jewish community in Yugoslavia proved much more significant than the proposed internal hierarchy. This paper examines how the organized emigration process was influenced by the internal hierarchy, how the proposed distribution of duties amongst various levels of participants functioned when applied to real problems and what led to this framework finally failing. Documents used in writing this paper are held at the Archives of the Jewish Historical Museum in Belgrade.
\end{abstract}

KEYWORDS: migration, structure, Jews, Yugoslavia, Israel

\section{Introduction}

The Federation of Jewish Religious Communities and Yugoslav state authorities started playing a notable role in the migration movement leading Jews to Palestine immediately after the National socialist party came to power in Germany in $1933 .{ }^{1}$ Jewish refugees coming from Western European coun-

\footnotetext{
${ }^{1}$ On interwar Jewish migration through Yugoslavia, see: Milan Ristović, „Jugoslavija i jevrejske izbeglice 1938-1941“, Istorija 20. veka, br. 1, (1996), 21-43; Milan Ristović, „Turisti pod sumnjom (o jednom vidu politike Kraljevine Jugoslavije prema jevrejskim izbeglicama 1938-1941. godine)“, u: Kladovo transport: Zbornik radova sa okruglog stola, urednik Andrej Mitrović (Beograd: Jevrejski istorijski muzej, 2006), 170-189; Milan Ristović, „Unsere und fremde Juden. Zum Problem der Jüdischen Flüchtlinge in Jugoslawien 1938-1941“, in: Zwischen grossen Erwartungen und bösem Erwachen. Juden, Politik und Antisemitismus in Ost- und Südosteuropa
} 
tries occupied or under pressure from the Third Reich, transited through the Kingdom of Yugoslavia in the interwar period en route to the British Mandate of Palestine. Although geopolitical circumstances had changed significantly, Yugoslavia was to play basically the same role during the first years following the end of the Second World War. ${ }^{2}$ Up until 1948 however, the Federation and Yugoslav state authorities were mostly passive bystanders, observing a flood of Jewish migrants on their way to Palestine. Although incoming refugees were helped along in every possible way, this did not affect the general way in which the migration process played out. A significant change in this regard followed only after an independent Jewish national state was proclaimed in Palestine.

Up until May $14^{\text {th }}$, 1948 Jewish immigration to Palestine was limited by British mandate regulations. ${ }^{3}$ What ensued after the independence of Israel was proclaimed, however, was one of the most massive migration movements of the XX century. Between 1948 and 1951 approximately 700.000 migrants from all over the world moved into the newly constituted Jewish state. ${ }^{4}$ A total of 7.739 Yugoslav Jews joined in this process. ${ }^{5}$ Starting in December of 1948 and ending in October of 1952, five separate waves of organized migration left Yugoslavia for Israel. ${ }^{6}$

The organizational framework of a process which was about to lead around two-thirds of Yugoslav Jews surviving the Second World War to Israel ${ }^{7}$ was defined by the Federation of Jewish religious communities in cooperation with state authorities. The basic idea for this structure was introducing different lower-level participants in charge of implementing decisions reached on the highest level. For this kind of system to work properly, a relatively rigid internal structure including a precise division of jurisdictions between different participating sides was put into place.

This paper focuses on the internal workings of organized Jewish migration from Yugoslavia to Israel - the placement and actions of different sides taking part in the movement in respect to what was officially proclaimed to be their role in the process. The interaction of Federation and state authorities has been for

1918-1945, Herausgegeben von Dittmar Dahlmann und Anke Hilbrenner (Paderborn München: Schöningh, 2007), 191-216; Anna Grünfelder, „Aufgeschobene Vernichtung. Jüdische Emigration nach Jugoslawien (1933-1938-1945)“, Südosteuropaforschung, Nr. 71, (2012), 233-284; Anna Maria Gruenfelder, „Nepoželjni gosti. Židovske izbeglice u Jugoslaviji (19381945)“, Zbornik Jevrejskog istorijskog muzeja, br. 10, (2015), 303-362.

${ }^{2}$ Mladenka Ivanković, „Odlazak jevrejskih izbeglica - žrtava Holokausta iz evropskih zemalja za Palestinu preko teritorije Jugoslavije 1946/47. godine“, Tokovi istorije, br. 3, (2006), 141-153.

${ }^{3}$ By far the most significant such regulation was the "White paper" of 1939, which was revoked only after the independence of Israel was proclaimed. See: „The British White Paper of 1939”, http://avalon.law.yale. edu/20th_century/brwh1939.asp (accessed 23. 1. 2018).

${ }^{4}$ Itzhak Alfassi, Immigration and Settlement (Jerusalem: Ketter Books, 1973), 56; Shoshanna Neumann, Aliyah to Israel: Immigration under Conditions of Adversity (Bonn: Forschungsinstitut zur Zukunft der Arbeit, 1999), 1-5.

${ }^{5}$ Милан Радовановић, „Поједини статистички аспекти организованог исељавања Јевреја из Југославије у Израел (1948-1952)“, Годишъак за друштвену историју, бр. 2, (2015), 66.

${ }^{6}$ Исто, 55-56.

${ }^{7}$ Исто, 68. 
the most part sidelined, although this specific context cannot be ignored in approaching the questions at hand. Apart from defining the basic mechanism of interactions within the Jewish community, this paper contemplates how efficient in fact the internal structure was when specific problems were to be dealt with.

So as to more precisely define the interaction of different sides within the Yugoslav Jewish community taking part in the process of organized migration to Israel, it was clearly differentiated between three singular perspectives. The migration was deconstructed and analyzed as consisting of three different, but mutually connected horizontal levels. ${ }^{8}$ The general differentiation is between states and organization on the first, collectives ${ }^{9}$ and groups ${ }^{10}$ on the second and, finally, individuals taking part in the migration on the third level of deconstruction.

Within the proposed methodological model, the Federation of Jewish religious communities is a participant belonging as much to the first as it does to the second level of analysis. In cooperating with state authorities, the Federation displayed mannerisms typical of organizations. On the other hand, in cooperating with the Jewish community, the Federation acted as a collective. The second level of deconstruction is by far the most complex, as it includes the last active (collectives) and first passive (groups) participants in the organized migration process. The most prominent collectives are local Jewish communities with one aspect of the Federations engagement. Groups taking part in the process were exceedingly diverse with the most important being individual families. ${ }^{11}$

The last level of deconstruction is a microhistorical one, ${ }^{12}$ encompassing the personal histories of individual participants. The perspective of collectives, groups and singular migrants were used as a counterpoint to the general

\footnotetext{
${ }^{8}$ More on this method in: Milan Radovanović, „The State, the Organization and the Individual - A three-level Approach to Migration“, in: Where is Civil Society in Central Europe heading to?, Edited by Inocent-Mária Staniszlo et al (Prešov: Michal Vaško Press, 2015), 169-187. and Милан Радовановић, „Исељавање Јевреја из Југославије у Израел (1948-1952)“, (докторска дисертација, Универзитет у Београду, Филозофски факултет, Одељење за историју, 2015) 6-11.

${ }^{9} \mathrm{~A}$ collective in this context is considered to be a number of individuals acting within a structured enviroment of interaction. General characteristics of collectives in this sense are identical to those of organizations as defined by Nikola Rot. See: Никола Рот, Психологија група. Изабрана дела - том IV (Београд: Завод за издавање уџбеника, 2010), 90-121.

${ }^{10}$ A group is to be understood as individuals informally connected and functioning parallel to formal structuress within the Jewish community. This definition combines the term group as used by sociology (See: Judy Gahagan, Interpersonal and Group Behaviour (London: Methuen, 1975, 100) and the term ,small group“ as used in psychology (See H. Рот, н. d., 52-53).

${ }^{11}$ Individual families are representative of small and intimate groups. More on intimate groups: Richard Crisp and Rhiannon Turner, Essential Social Psychology (London: Sage, 2007), 105106. Apart from a common goal, a specific structure, group norms and member consciousness about belonging to a group, small groups are defined by a limited number of members, direct interaction between them, mutual dependence and mutual influence between singular members. More on that: Н. Рот, $\mu$. ..., 52-53.

12 Towards a microhistorical approach to history and a „bottom-up“ perspective in historiography see: Andrew Port, „History from Below, the History of Everyday Life, and Microhistory”, in: International Encyclopedia of the Social \& Behavioral Sciences, 2nd edition, volume 11 (Oxford: Pergamon Press, 2015), 108-113.
} 
framework of the organized migration from Yugoslavia to Israel and a base for analyzing how efficient the proposed structure in fact was when confronted with specific problems arising from the process.

\section{Internal Structure and Internal Exceptions}

Being the official representative of the Jewish community in post-war Yugoslavia enabled the Federation to directly communicate with state officials in charge of different aspects of organized migration. ${ }^{13}$ This fact alone was enough to secure the top spot within the internal structure of the process for the central organization of Jews in Yugoslavia.

Consisting of the Federation of Jewish religious communities Executive Board members, the Central emigration Commission (Glavna komisija za iseljenje) was formed in Belgrade in March of $1948 .{ }^{14}$ This commission was to coordinate various activities leading up to the moment when the forthcoming wave of migrants was to leave the country. ${ }^{15}$ The same was expected from Regional emigration commissions (Okružne komisije za iseljenje) within the territories assigned to them. ${ }^{16}$ Leading up to the first migration wave, Regional commissions were constituted in Belgrade (for the territories of Serbia and the Banat), Novi Sad and Subotica (the Bačka), Zagreb (Croatia and Slovenia), Sarajevo (Bosnia and Herzegovina) and Skopje (Macedonia with Kosovo and Metohija). ${ }^{17}$ This original model suffered several changes even before the first wave of organized emigration was to leave Yugoslavia. ${ }^{18}$

${ }^{13}$ In more detail about the role played by the Federation of Jewish religious communities in the organized emigration process, see: Milan Radovanović, „The State, the Organization and the Individual - A three-level Approach to Migration“, 174-176.

${ }^{14}$ At the time of its constitution, the Central emigration Commission consisted of the following Federation Executive Board members: Lavoslav Kadelburg (also vice-president of the Federation), David Alkalaj (also president of the Jewish religious community of Belgrade and of the Autonomous Board), Bencion Levi, Martin Komloš, Sima Alkalaj and Aleksandar Levi. Naftalio Bata Gedalja, secretary of the Federation, was also named secretary of the Central emigration Comission. Arhive of the Jewish Historical Museum (AJHM), Provisional box (p. b.) 781 (Arhiv Perera 2-3), Zapisnik XXXV sednice Izvršnog odbora Saveza jevrejskih veroispovednih opština Jugoslavije (IO SJVOJ), 4. avgust 1948.

15 The main executive body of the Federation was the Presidency (Predsedništvo) which acted through its three governing bodies (the Executive Board, the Central Board (Glavni odbor) and the Autonomous Board (Autonomni odbor). More on the subject: Mladenka Ivanković, Jevreji u Jugoslaviji (1944-1952), Kraj ili novi početak (Beograd; Institut za noviju istoriju Srbije, 2009), 109-110.

${ }^{16}$ AJHM, p. b. 781 (Arhiv Perera 2-3), Zapisnik XXXVI sednice IO SJVOJ, 12. avgust 1948.

${ }^{17}$ Towards administrative changes within the Federation and the Yugoslav Jewish community, in general, preceding organized emigration to Israel, see: AJHM, Aliyah (Al.) 1948-1951, p. b. 768, Dopis SJVOJ, svim jevrejskim veroispovednim opštinama Jugoslavije, Predmet: Odlazak u državu Izrael, 7. avgust 1948, Pov. br. 1132/48.

18 AJHM, Al.1948, p. b. 827, Dopis SJVOJ, svim jevrejskim veroispovednim opštinama Jugoslavije, Predmet: Drugo iseljenje u državu Izrael, 19. februar 1949, Pov. br. 342/49; AJHM, Al. 1949 , p. b. 1288, Dopis SJVOJ, svim jevrejskim veroispovednim opštinama Jugoslavije (Cirkular br. I), Predmet: Treće iseljenje u državu Izrael, 23. oktobar 1949, Pov. br. 3481/49; AJHM, 
The number of Regional commissions was boiled down from six to four by the end of 1948, with their jurisdictions appropriately modified. The burden of preparing the first wave of organized emigration fell upon the Regional commissions in Belgrade (for the territories of Serbia, Macedonia, Montenegro, Kosovo and Metohija), Zagreb (Croatia and Slovenia), Sarajevo (Bosnia and Hercegovina) and Novi Sad (Vojvodina). ${ }^{19}$ This network only kept on changing during future migration waves.

Regional commissions in Belgrade (for the territories of Serbia and Montenegro), Zagreb (Croatia and Slovenia), Sarajevo (Bosnia and Herzegovina) and Skopje (Macedonia) played the main role in preparing the organized migration wave mid-1949. ${ }^{20}$ The following year, the Regional Commission in Skopje was revoked and the territory of Macedonia came under the jurisdiction of Belgrade. ${ }^{21}$ In May of 1951 the Regional commission in Novi Sad was reconstituted, dealing with migrants coming from the Jewish communities in Vojvodina. ${ }^{22}$ Documents at hand don't mention any kind of change within the network of Regional commissions preceding the fifth and final wave of organized emigration. ${ }^{23}$ However, it is safe to assume that the minimal number of Yugoslav Jews participating in the fifth migration wave of October $1952^{24}$ lead to some modifications of existing organizational procedure.

Within every single wave of organized emigration from Yugoslavia to Israel, the Central emigration commission was to communicate information relevant to the process to Regional Commissions. Regional commissions would then pass the information on to Local emigration commissions (Opštinske komisije za iseljenje) functioning with communities under their authority. Local commissions were given the task of keeping the members of their own communities informed about different aspects of the migration process. The same rules were to be applied to communication going in the opposite direction. Jurisdiction was moved upwards in accordance with the nature of the problem at hand. Individual migrants were instructed to approach commissions working with the local Jewish community, which would then, if necessary, communicate the is-

Al. 1948, p. b. 827, Dopis svim jevrejskim veroispovednim opštinama Jugoslavije (Cirkular br. I), Predmet: Četvrto grupno iseljenje u državu Izrael, 29. januar 1951, Pov. br. 184/51; AJHM, Al. 1948, p. b. 855, Dopis SJVOJ, svim jevrejskim veroispovednim opštinama Jugoslavije (Cirkular br. I), Predmet: Peto grupno iseljenje u državu, 12. april 1952, Pov. br. 604/52.

19 See: AJHM, Al. 1950, p. b. 755, Dopis SJVOJ, svim jevrejskim veroispovednim opštinama Jugoslavije, Predmet: Odlazak u državu Izrael, 26. avgust 1948, Pov. br. 1216/48.

${ }^{20}$ AJHM, Al. 1948, p. b. 827, Dopis SJVOJ, svim jevrejskim veroispovednim opštinama Jugoslavije, Predmet: Drugo iseljenje u državu Izrael, 19. februar 1949, Pov. br. 342/49.

${ }^{21}$ AJHM, Al. 1949, p. b. 1288, Dopis SJVOJ, svim jevrejskim veroispovednim opštinama Jugoslavije, Predmet: Treće iseljenje u državu Izrael, 23. oktobar 1949, Pov. br. 3481/49;

${ }^{22}$ AJHM, Al. 1948, p. b. 827, Dopis SJVOJ, svim jevrejskim veroispovednim opštinama Jugoslavije (Cirkular br. I), Predmet: Četvrto grupno iseljenje u državu Izrael, 29. januar 1951, Pov. br. 184/51.

${ }^{23}$ AJHM, Al. 1948, p. b. 855, Dopis SJVOJ, svim jevrejskim veroispovednim opštinama u Jugoslaviji (Cirkular br. I), Predmet: Peto grupno iseljnje u državu Izrael, 12. april 1952, Pov. br. 604/52.

24 A total of 84 emigres left Yugoslavia at this time. See: М. Радовановић, „Поједини статистички аспекти““..., 66. 
sue at hand to the controlling Regional commission. Problems faced by individual émigrés were to be passed on to the Federation (the Central emigration commission) only if no adequate solution could be found on the local or regional level. Finally, solely Federation executives were in a position to contact state authorities if the need for such an intervention arises. ${ }^{25}$

In mediating between the Jewish community and state authorities, Federation executives actually sought to create a sort of control barrier separating the two sides. They feared that an individual directly addressing the state might compromise the idea of Yugoslav Jews being completely integrated into postwar communist society. ${ }^{26}$ It is in this context that the warning Federation executives repeated with every wave of migrants leaving Yugoslavia should be un-

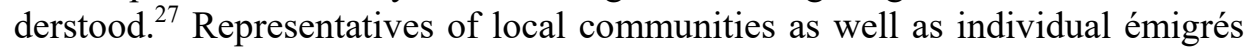
were repeatedly and explicitly forbidden from directly contacting Yugoslav state authorities under any circumstances.

\section{Collectives Defying Structuring}

The proposed internal structure of organized Jewish emigration from Yugoslavia to Israel could only partially be implemented. Information was forwarded to all of the sides participating in the migration without any significant problems. The reverse was however not true. The proposed way of communicating specific problems to higher authorities clashed on principle with the way in which the local communities and individual émigrés understood their own role in the migration movement.

\footnotetext{
${ }^{25}$ A number of such cases can be found in AJHM, Al. 1948-1951, p. b. 880.

${ }^{26}$ The Jewish community enjoyed a somewhat privileged position in post-war Yugoslavia, due to a significant number of Jews taking part in the communist resistance movement during World War Two. The integration of Jews into the socio-political context of a communist state was marked by members of the Communist Party being voted into executive positions in the Federation. M. Ivanković, $n$. $d$., 112-113. On the way in which this policy reflected upon the organized emigration to Israel see: Милан Радовановић, „Ционизам и прагматизам - Зашто су се југословенски Јевреји иселили у Израел? (1948-1952)“, Београдски историјски гласник, бр. 6, (2015), 215-249.

27 „Individual emigres should on principle not contact state authorities, unless in situations where explicitly called upon to do so. When in need of information or dealing with problems pertatining to the migration process, they should adress the local community which will then attempt to deal with issues at hand in the fastest and most fortuitous way". See: AJHM, Al. 1950, p. b. 755, Dopis SJVOJ, svim jevrejskim veroispovednim opštinama Jugoslavije, Predmet: Odlazak u državu Izrael, 26. avgust 1948, Pov. br. 1216/48; AJHM, Al. 1948, p. b. 827, Dopis SJVOJ, svim jevrejskim veroispovednim opštinama Jugoslavije, Predmet: Drugo iseljenje u državu Izrael, 19. februar 1949, Pov. br. 342/49; AJHM, Al. 1949, p. b. 1288, Dopis SJVOJ, svim jevrejskim veroispovednim opštinama Jugoslavije (Cirkular br. I), Predmet: Treće iseljenje u državu Izrael, 23. oktobar 1949, Pov. br. 3481/49; AJHM, Al. 1948, p. b. 827, Dopis SJVOJ, svim jevrejskim veroispovednim opštinama Jugoslavije (Cirkular br. I), Predmet: Četvrto grupno iseljenje u državu Izrael, 29. januar 1951, Pov. br. 184/51; AJHM, Al. 1948, p. b. 855, Dopis SJVOJ, svim jevrejskim veroispovednim opštinama u Jugoslaviji (Cirkular br. I), Predmet: Peto grupno iseljenje u državu Izrael, 12. april 1952, Pov. br. 604/52.
} 
Straying from the proposed communication model is most noticeable when observing the activities of Regional Commissions. Although local communities were obliged to communicate their problems to the Federation via Regional commissions only rarely did they actually do so. Local officials, as well as individuals, tended to, whenever possible, address the Federation directly. This basically meant the Regional commissions were rendered completely useless. ${ }^{28}$ Apart from the idea being fundamentally flawed, there were also numerous practical problems with how the Regional Commissions were supposed to function. Probably the most important one was them constantly being moved around.

Because of Regional commissions being reconstituted with every single wave of organized emigration from Yugoslavia to Israel officials of local communities were often confused by the range of their jurisdictions. One example is especially notable. Officials of the Novi Sad community directed one very simple question at the Federation in March of $1951 .{ }^{29}$ Confronted with conflicting information and numerous inquiries from individual émigrés, members of the Regional Commission in Novi Sad were finally forced to ask Federation officials: ,What communities are we in charge of?“30

The confusion of community officials with the role to be played by Regional commissions simply translated to the level of individuals taking part in the migration. This is best exemplified by individuals deciding on not leaving the country after all, usually at the last moment. ${ }^{31}$ Canceling an application meant sending an official notice to the Local commission, which would then be passed on to the Regional Commission and then, finally, to the Federation. Federation executives would gather all of the revoked applications and then dispatch them to the Ministry of internal affairs. Documents at hand, however, show most of the participating sides completely ignoring this procedure.

\footnotetext{
${ }^{28}$ Ignoring the jurisdiction of Regional commissions can also be attributed to them not being part of a traditional institution within the Yugoslav Jewish community. The Federation and local communities played significant roles within the community independently of the migration context. The idea of regional centers was, on the other hand, specific to organized Jewish emigration from Yugoslavia to Israel. This has to have influenced the way in which emigres and local communities perceived Regional Commissions.

${ }^{29}$ AJHM, Al. 1948, p. b. 757, Dopis JVO Novi Sad, SJVOJ-u, 23. mart 1951.

${ }^{30}$ „Koje opštine padaju pod nas?“ (sic!), Ibid.

${ }^{31}$ Most such inquiries made by individual emigres can be found in: AJHM, Al. 1948, p. k. 827. Every individual application was to be accompanied by a formal unsigned request to be released from Yugoslav citizenship. The Federation would then forward these requests to the Ministry of internal affairs (Ministarstvo unutrašnjih poslova Jugoslavije). In the case of the application being successful, future émigrés were called upon to come to the local division of the Ministry to sign the request. This was the formal end to the emigration process before actually leaving the country. Up until this moment, however, individuals were free to revoke their applications. See: AJHM, Al. 1948-1951, p. b. 768, Dopis SJVOJ, svim jevrejskim veroispovednim opštinama Jugoslavije, Predmet: Odlazak u državu Izrael, 7. avgust 1948, Pov. br. 1132/48; AJHM, Al. 827, Dopis SJVOJ, svim jevrejskim veroispovednim opštinama Jugoslavije, Predmet: Drugo iseljenje u državu Izrael, 19. februar 1949, Pov. br. 342/49; AJHM, Al. 1948, p. b. 855, Dopis SJVOJ, svim jevrejskim veroispovednim opštinama Jugoslavije, Predmet: Peto grupno iseljenje u državu Izrael (Cirkular br. I), 12. april 1952, Pov. br. 604/52.
} 
Most individuals attempted to revoke their application by directly addressing the Federation of Jewish religious communities of Yugoslavia. ${ }^{32}$ This basically meant completely ignoring the role to be played by Local and Regional Commissions. A similar level of disrespect for any kind of structure was demonstrated by officials of local communities. Instead of addressing Regional commissions with notices on their members revoking their applications, they usually just sent them to the Federation. ${ }^{33}$ Finally, there are also examples of individuals addressing Regional commissions bypassing the local ones. ${ }^{34}$

Although the number of exceptions tells the story of an internal structure never being applied, it must be noted that it wasn't completely ignored either. Although they were relatively scarce, there are examples of individuals addressing local communities with notices about revoking their application. ${ }^{35}$ Appropriately, there are also cases of local communities collecting revocation notices and passing them along to Regional commissions in the form of a list of people who decided to stay in Yugoslavia after all. ${ }^{36}$

Apart from individuals and community officials completely ignoring the jurisdictions of higher authorities, the proposed structure of the migration process suffered the most damage because of how participating sides understood their own role in it. This mainly applies to singular communities who perceived themselves as being the only legitimate representative of their members leaving the country. Although the Federations supreme authority was never formally questioned, executives of local communities insisted they were themselves most qualified to represent individual émigrés. Most indicative in this sense is the correspondence between Federation executives and the community

32 See, for example: AJHM, Al. 1948, p. b. 827, Dopis Hamburger Irene iz Novog Sada, SJVOJu, 27. oktobar 1948, Pov. br. 1737/48; AJHM, Al. 1948, p. b. 827, Dopis Leona Levija, SJVOJu, 2. novembar 1948, Pov. br. 1873/48: AJHM, Al. 1948, p. b. 757, Dopis Vladislava Bruka, SJVOJ-u, 6. maj 1949, Pov. br. 1181/49; AJHM, Al. 1948, p. b. 757, Dopis Manojla Rubena, SJVOJ-u, Komisiji za iseljenje, 23. maj 1949; AJHM, Al. 1948-1951, p. k. 758, Dopis Marinović Slavije, SJVOJ-u, 26. januar 1950.

${ }^{33}$ See: AJHM, Al. 1948, p. b. 855, Dopis JVO Subotice, SJVOJ-u, 17. novembar 1948; AJHM, p. b. 738, Dopis JVO Subotica, SJVOJ-u, Predmet: Odustajanje Haner Ane, 2. jun 1949, Pov. br. 1766/48; AJHM, Al. 1948, p. b. 827, Dopis JVO Pančevo, SJVOJ-u, 19. novembar 1948, Pov. br. 2262/48; AJHM, Al. 1948-1949, p. b. 897, Dopis JVO Zagreb, Zajednice u Ljubljani, SJVOJ-u, 6. jun 1949; AJHM, Al 1948-1951, p. b. 758, Dopis JVO Subotice, SJVOJ-u, 30. januar 1950; AJHM, Al. 1948-1951, p. b. 758, Telegram JVO Osijek, SJVOJ-u, 5. mart 1950.

${ }^{34}$ AJHM, Al. 1948, p. b. 827, Dopis Rudolfa Vinarica, Okružnoj komisiji za iseljenje Jevreja u Beogradu, 17. oktobar 1948, Pov. br. 1778/48.

${ }^{35}$ AJHM, Al. 1948, p. b. 827, Dopis Aleksandra Franka, JVO Zemun,, 30. oktobar 1948; AJHM, Al. 1948. p. b. 827, Dopis Slobodanke Papo, JVO Beograd, 2. novembar 1948; AJHM, Al. 1948, p. b. 757, Dopis Hauzer Marije, JVO Novi Sad, maj 1949; AJHM, Al. 1948, p. b. 757, Dopis Kornel Horovica, JVO Beograd, 26. maj 1949; AJHM, Al. 1950-1952, p. b. 756, Dopis Šenfeld Bertalana, JVO Beograd, 4. januar 1950.

${ }^{36}$ AJHM, Al. 1948, p. b. 860, Dopis JVO Dubrovnik, Okružnoj komisiji za Izrael kod JVO Sarajevo, Predmet: Traženje pobližih uputstava za selidbene stvari onih iseljnika čije se stvari šalju iz pomorskih gradova Jugoslavije, 11. oktobar 1948, Pov. br. 1647/48; AJHM, Al. 1948-1949, p. b. 897, Dopis JVO Zagreb, Zajednice u Ljubljani, Okružnoj komisiji za iseljenje pri JVO Zagreb, 25. jun 1949. 
of Osijek, concerning financial aid to be distributed amongst the participants of the second wave of organized emigration. ${ }^{37}$

A meeting of Jewish community representatives was called in Belgrade for the end of October $1949 .{ }^{38}$ The central question to be answered at this time was how financial aid was to be distributed among émigrés leaving the country with the third wave of organized emigration. Representatives of the Osijek community seized the opportunity at hand to complain about not being invited to a similar meeting held leading up to the previous migration wave. As community representatives were not present to fight for their cause, they pointed out; émigrés from Osijek got significantly less of a financial boost than those coming from other communities. ${ }^{39}$

A complaint the Federation received from Apatin community executives as preparations for the first wave of emigration neared their end is also a shining example of how much local communities were set on representing their members taking part in the migration. ${ }^{40}$ The local community, because of reasons unknown, omitted to pass on information relevant to the process to local émigrés. Because of this, individuals directed their questions at the community in Subotica. ${ }^{41}$ Apatin community officials interpreted this as directly denying their sovereign position within organized emigration. With a hint of bitterness, they pointed out that local executives would take no responsibility for something possibly going wrong because of émigrés acting recklessly and approaching the Subotica community for information. ${ }^{42}$

The internal structure of organized emigration, as defined by Jewish community officials, was from the beginning on compromised by local communities attempting to influence the makeup of the process as a whole. What however brought about the final downfall of the system was individual émigrés trying to do the same.

${ }^{37}$ Towards the way in which financial aid was distributed amongst Jews leaving Yugoslavia for Israel as part of the organized emigration movement, see: Милан Радованвовић, „Поједини економски аспекти организованог исељавања југословенских Јевреја у Израел 1948/9. године“, Годишъьк за друштвену историју, бр. 3, (2011), 87-92. and Милан Радовановић, „Организована емиграција капитала - „Збирни рачун репатрираца за Израел“ (19481952)“, Архив, бр. 1-2, (2017), 164-184.

${ }_{38}$ AJHM, Al. 1950-1951, p. b. 743, Dopis JVO Osijek, SJVOJ-u, 29. oktobar 1949, Pov. br. 3548/49.

${ }^{39}$ The circumstances of the Osijek community being left out of the meeting held in preparation of the second wave of organized emigration are unclear. Osijek community executives kept insisting that because of this fact insufficient funds were assigned to local émigrés. Federation executives, on the other hand, claimed that émigrés from Osijek hadn't even applied for financial help at that time and that, therefore, their representatives had no place being in the meeting. See: AJHM, Al. 1950-1951, p. b. 743, Dopis SJVOJ, JVO Osijek, 2. novembar 1949, Pov. br. 3548/49. Whatever the reasons behind this decision were, not including Osijek community officials in the meeting was viewed as depriving them of the right to represent their members. See: AJHM, Al. 19501951, p. b. 743, Dopis JVO Osijek, SJVOJ-u, 29. oktobar 1949, Pov. br. 3548/49.

${ }^{40}$ AJHM, Al. 1949, p. b. 906, Dopis JVO Apatin, SJVOJ-u, 6. novembar 1948, Pov. br. 1912/48.

${ }^{41}$ It is said that applicants directed their questions at the Regional Commission in Subotica, Ibid. As the Regional Commission for the Vojvodina was at this time located in Novi Sad, it remains unclear what Apatin community officials actually referring to.

${ }^{42}$ Ibid. 


\section{Individuals Defying Structuring}

With some fluctuations in singular years, Jews made up approximately $0.5 \%$ of the population of the Kingdom of Yugoslavia. ${ }^{43}$ The size of the Jewish community leads to it being atypically integrated, especially when observed on a local scale. This is most apparent when compared to other religious and national communities living in Yugoslavia. ${ }^{44}$ Losing approximately $80 \%$ of their members in the Holocaust ${ }^{45}$ homogenized the remaining members of the community even more. ${ }^{46}$ The process of organized emigration to Israel necessarily reflected a level of integration this high. Individuals moving to Israel weren't shy about using any kind of personal connection to make their own and the position of family members in the process more advantageous. Every single participant was actually attempting to adapt the migration so as to suit their own needs. Whatever internal structure was to be implemented was at this point abandoned in favor of a completely personalized understanding of mass emigration.

Because he occupied the highest position within the community, most émigrés turned to Albert Vajs when attempting to somehow advance their own position in the organized emigration from Yugoslavia to Israel. ${ }^{47}$ The most de-

${ }^{43}$ See in detail: Милан Кољанин, Јевреји и антисемитизам у Краљевини Југославији 1918 1941 (Београд: Институт за савремену историју, 2008), 48-49.

${ }^{44}$ In the sense of its members directly interacting, the Jewish community of Yugoslavia cannot be considered a „small group“ (See: Н. Рот, н. $\partial ., 52-53$ ). On the other hand, the compactness demonstrated by the Yugoslav Jewish community in the post-war period leads to it being classified higher than just a loose collection of people in the sense of entitativity that other religious and national groups have to be classified as. More on entitativity and classifying groups in accordance see: R. Crisp and R. Turner, op. cit., 105-106.

${ }^{45}$ Albert Vajs, „Jevreji u novoj Jugoslaviji“, Jevrejski almanah, (1954), 125-126. Existing estimates vary, but one can assume there were around 12500 Jews living in Yugoslavia post World War Two. See: Ari Kerkkänen, Yugoslav Jewry: Aspects of post-World War II and postYugoslav developments (Helsinki: Finnish Oriental Society, 2001), 42; M. Ivanković, $n$. d., 79; Marko Perić i Srećko Stanić, „Jevreji Beograda u popisima stanovništva XIX i XX veka“, Zbornik Jevrejskog istorijskog muzeja, br. 6, (1992), 294-295.

46 This is an example of how group size influences its internal cohesion. Cohesion is one of the ways in which a group is defined as such and basically determines the level to which an individual acts accordingly to group interests. See: R. Crisp and R. Turner, op. cit., 105.

${ }^{47}$ Albert Vajs (Zemun, October 3rd 1905 - Belgrade, April 4th 1964) studied philosophy, economy and law in Berlin, Paris, Belgrade and Zagreb. He got his law degree from the University of Zagreb. He got his Ph. D. in 1928. After passing the bar exam, he started working in Belgrade. During his studies in Zagreb, he became an active member of different local Jewish youth organizations. After having been elected member of the Executive Boards of the Federation of Jewish religious communities and the Zionist Federation of Yugoslavia in 1928, he was elected as the vice-president of the Ashkenazi Jewish religious community in Belgrade. During the April war, he was mobilized as an officer with the military reserve. After the Kingdom of Yugoslavia had capitulated, he was lead off to Germany as a prisoner of war. Upon returning to Yugoslavia, Vajs was assisting the „State commission for determining the crimes of occupying forces and their abetters" (Државна комисија за утврђивање злочина окупатора и њихових помагача) (1945-1948). He participated in preparing the indictment and accompanying evidence as a member of the Yugoslav delegation in the Nuremberg trial. He was appointed coun- 
tailed such account to be found in documents at hand is that of married couple Bergštajn coming from Bjelovar.

One of the migrants who left Yugoslavia for Israel with the first wave of organized emigration wrote a letter to Albert Vajs in April of $1949 .{ }^{48} \mathrm{He}$ approached the president of the Federation hoping he might be able to help his cousin Erna Bernštajn and her husband emigrate. Up to that point they had both applied and produced all of the necessary paperwork for them to leave with the second wave of organized emigration. However, a problem arose that they themselves could not solve.

During the war, Naftali Bergštajn had suffered from typhoid fever, which caused him to develop a severe heart defect. ${ }^{49}$ Because of his illness, he was not allowed to migrate to Israel in $1948 .^{50}$ Not willing to part with her husband, Erna Bernštajn passed up the opportunity to leave the country herself. Objectively speaking it was not to be expected for any future application of Naftali Bergštajn to be resolved positively. ${ }^{51} \mathrm{He}$, therefore, turned to Albert

selor to the Yugoslav Embassy in Washington in 1955, taking part in the process of extraditing Andrija Artuković. He assisted in the preparation of indictment material for the trial of Adolf Eichmann. As of 1947 he was employed as a part-time teacher at the Faculty of Law in Belgrade. Rising through the academic ranks, he was finally promoted to full professor in 1961 . He participated in reconstructing the Federation of Jewish religious communities in post-war Yugoslavia. He was appointed vice-president in 1945, performing this duty until 1948. As of 1948, up until his death in 1964, he was president of the Federation. He was the Federation delegate to the European conference of the World Jewish Congress (WJC) in Paris (1945). He would later be elected member of the Executive Board of the WJC. See in detail: Александар Рафаиловић, „Вајс, Алберт“, у: Знаменити Јевреји Србије (Београд: Савез јеврејских општина Србије, 2011) 50-51.

${ }^{48}$ AJHM, Al. 1949, p. b. 753, Pismo, 29. april 1949.

${ }^{49}$ Ibid.

${ }^{50}$ From the first wave of organized emigration onward, one of the documents every migrant had to enclose to his application was a certificate of health. See: AJHM, Al. 1948-1951, p. b. 768, Dopis SJVOJ, svim jevrejskim veroispovednim opštinama Jugoslavije, Predmet: Odlazak u državu Izrael, 15. septembar 1948, Pov. br. 1367/48; AJHM, Al.1948, p. b. 827, Dopis SJVOJ, svim jevrejskim veroispovednim opštinama Jugoslavije, Predmet: Drugo iseljenje u državu Izrael, 19. februar 1949, Pov. br. 342/49; AJHM, Al. 1949, p. b. 1288, Dopis SJVOJ, svim jevrejskim veroispovednim opštinama Jugoslavije (Cirkular br. I), Predmet: Treće iseljenje u državu Izrael, 23. oktobar 1949, Pov. br. 3481/49; AJHM, p. k. 869, Dopis SJVOJ, svim jevrejskim veroispovednim opštinama Jugoslavije, Predmet: Četvrto grupno iseljenje u državu Izrael (Cirkular br. IV), 26. mart 1951, Pov. br. 574/51; AJHM, Al. 1948, p. b. 855, Dopis SJVOJ, svim jevrejskim veroispovednim opštinama Jugoslavije, Predmet: Peto grupno iseljenje u državu Izrael (Cirkular br. IV), 25. jun 1952, Pov. br. 1113/52. Strict control of the immigrants health was officially justified by the need to protect public health in the newly formed Jewish state and hinder the spreading of infectious diseases. Realistically, however, this rule was introduced so as to single out applicants who were unable to do military service or actively participate in building out the newly established Jewish state. Conditions referring to the immigrant's health were so important, they were introduced into the Law of Return in 1950. See: Law of Return 5710-1950 (05 Jul 1950), http://www.mfa. gov. il/mfa/mfa-archive/1950-1959/pages/ law\%20of\%20return\%205710-1950.aspx (accessed 25. 4. 2018).

${ }^{51}$ A severe heart defect certainly was not an illness that could endanger public health. Being unable to serve in the Israeli army made Bernštajn an unwanted immigrant nonetheless. 
Vajs, hoping he would somehow be able to influence the migration process. Bergštajn reached out to the president of the Federation through an anonymous cousin who was, in a way undisclosed in the documents at hand, close to Vajs. ${ }^{52}$

The example of the Bernštajns distinctly shows that any kind of proposed internal structure of organized migration was ignored on the part of individuals taking part in the process. Furthermore, it demonstrates how flawed an individuals understanding of the duties of different sides defining the mass emigration from Yugoslavia to Israel was. Any individual unfamiliar with the supposed model of interaction between Local commissions, Regional Commissions, the Central commission and state authorities, was forced to rely on a personalized and therefore completely arbitrary understanding of the process. Only one aspect of this flawed understanding was randomly attributing authority in dealing with certain questions to participants defining the migration closest to them. In this sense, it was typical to view the Federation executives as being the final instance in defining every single aspect of the migration and as being able to freely adapt the process so as to suit the needs of individual participants.

What Naftali Bernštajn expected Albert Vajs to do was somehow enable him to leave the country within the regular emigration procedure, even with him suffering a serious heart defect. ${ }^{53}$ As the very strict health conditions to be met by migrants coming to Israel hadn't changed up until the very end of the organized immigration from Yugoslavia, there was no reason for Bernštajn to think he would be allowed to join in the process. ${ }^{54} \mathrm{He}$ and his wife, however, left the country mid1949. ${ }^{55}$ Documents at hand don't show how much Albert Vajs actually influenced this outcome, but it must be viewed as symptomatic that it was the two migrants who directly approached him directly that made it to Israel in the end.

Similar to the letter received from Naftali and Erna Bernštajn was one sent to the president of the Federation by Dragutin Vajs, coming from Zagreb. ${ }^{56}$ Applying for migration with his partner and their daughter, Vajs was denied permition to leave the country mid 1949. In his letter he states that the main reason for not being allowed to join in the organized migration process was him living out of wedlock with his partner, who herself was a non-Jew. In accordance, their daughter was of half-Jewish descent. Rules of organized migration from Yugoslavia to Israel stated that women of non-Jewish descent could only

52 One should note that the émigré addresses Albert Vajs as being an „old friend“, AJHM, Al. 1949, p. b. 753, Pismo, 29. april 1949.

${ }^{53}$ Ibid.

${ }^{54}$ See: AJHM, Al.1948, p. b. 827, Dopis SJVOJ, svim jevrejskim veroispovednim opštinama Jugoslavije, Predmet: Drugo iseljenje u državu Izrael, 19. februar 1949, Pov. br. 342/49; AJHM, Al. 1949, p. b. 1288, Dopis SJVOJ, svim jevrejskim veroispovednim opštinama Jugoslavije (Cirkular br. I), Predmet: Treće iseljenje u državu Izrael, 23. oktobar 1949, Pov. br. 3481/49; AJHM, p. k. 869, Dopis SJVOJ, svim jevrejskim veroispovednim opštinama Jugoslavije, Predmet: Četvrto grupno iseljenje u državu Izrael (Cirkular br. IV), 26. mart 1951, Pov. br. 574/51; AJHM, Al. 1948, p. b. 855, Dopis SJVOJ, svim jevrejskim veroispovednim opštinama Jugoslavije, Predmet: Peto grupno iseljenje u državu Izrael (Cirkular br. IV), 25. jun 1952, Pov. br. 1113/52.

${ }^{55}$ AJHM, Al. 1949, p. b. 1288, Spisak iseljenika za Izrael, VI-VII 1949.

${ }^{56}$ AJHM, Al. 1950-1952, p. b. 756, Dopis Dragutina Vajsa, Albertu Vajsu, 27. oktobar 1949. 
join in the migration if they were married to a Jewish man. ${ }^{57}$ Children from mixed marriages had to be of the Jewish faith so as to be allowed to migrate to Israel. It seems that applications of the wife and daughter of Dragutin Vajs were rejected completely in accordance with these preset rules.

The case of Naftali and Erna Bernštajn was an indirect attempt of individual émigrés to adapt the migration process to their own needs by reaching out to the president of the Federation. Dragutin Vajs goes a step further by directly pointing out that this was indeed his goal when approaching Albert Vajs. ${ }^{58}$ His letter reads "you sitting in Belgrade (Federation executives, authors note) are all powerful when it comes to these issues (pertaining to the organized migration process, authors note)“, therefore he expects his needs to be met. It seems however, Dragutin Vajs was not granted his request. The list of Jewish émigrés leaving Yugoslavia with the third wave of organized emigration contains the name of Dragutin Vajs, but also a note explicitly saying that his wife did not join him on this occasion. ${ }^{59}$ As the name of their daughter is unknown, ${ }^{60}$ it remains possible for her to have joined her father in March of 1950 in leaving for Israel.

Apart from attempting to secure their own and the place of family members in the migration, individuals also approached the president of the Federation with far more everyday problems pertaining to the process. One example is that of Edita Šosberger from Dubrovnik, approaching Albert Vajs mid-1949 wanting to know if the migration would progress in a mass form or would be continued at an individual level. ${ }^{61}$

After having left the country and settling in Jerusalem in 1948, Moša Medina approached the president for the Federation requesting he help him get to his personal belongings left behind in Yugoslavia. ${ }^{62}$ These were deposited with the State Security Service branch (Uprava državne bezbednosti) in Belgrade.$^{63}$ It seems

${ }^{57}$ See: AJHM, Al. 1950, p. b. 755, Dopis SJVOJ, svim jevrejskim veroispovednim opštinama Jugoslavije, Predmet: Odlazak u državu Izrael, 26. avgust 1948, Pov. br. 1216/48; AJHM, Al. 1948 , p. b. 827, Dopis SJVOJ, svim jevrejskim veroispovednim opštinama Jugoslavije, Predmet: Drugo iseljenje u državu Izrael, 19. februar 1949, Pov. br. 342/49; AJHM, Al. 1949, p. b. 1288, Dopis SJVOJ, svim jevrejskim veroispovednim opštinama Jugoslavije (Cirkular br. I), Predmet: Treće iseljenje u državu Izrael, 23. oktobar 1949, Pov. br. 3481/49; AJHM, Al. 1948, p. b. 827, Dopis svim jevrejskim veroispovednim opštinama Jugoslavije (Cirkular br. I), Predmet: Četvrto grupno iseljenje u državu Izrael, 29. januar 1951, Pov. br. 184/51; AJHM, Al. 1948, p. b. 855, Dopis SJVOJ, svim jevrejskim veroispovednim opštinama Jugoslavije (Cirkular br. I), Predmet: Peto grupno iseljenje u državu, 12. april 1952, Pov. br. 604/52.

58 AJHM, Al. 1950-1952, p. b. 756, Dopis Dragutina Vajsa, Albertu Vajsu, 27. oktobar 1949.

${ }^{59}$ AJHM, Al. 1949, p. b. 1288, Spisak iseljenika (III alija)

${ }^{60}$ AJHM, Al. 1950-1952, p. b. 756, Dopis Dragutina Vajsa, Albertu Vajsu, 27. oktobar 1949.

${ }^{61}$ AJHM, Al. 1948, p. b. 757, Dopis Šosberger Edite iz Dubrovnika, predsedniku SJVOJ, Albertu Vajsu, 5. maj 1949. For the Federations answer, see: AJHM, Al. 1948, p. b. 757, Dopis SJVOJ, Šosberger Editi iz Dubrovnika, Predmet: Izrael, 16. maj 1949, Pov. br. 1324/49.

${ }^{62}$ The items at hand were two wallets, a cigar case, a watch, glasses, a pen, scissors, a pocket knife, a lighter, four keys, a pocket mirror, a badge of the Association of War veterans of the National liberation army, a can opener, a pencil lead, a toothpick and tweezers. See: AJHM, Al. 1948, p. b. 757, Dopis SJVOJ, Moši Farkiću, 12. septembar 1949, Pov. br. 3184/49.

${ }^{63}$ AJHM, Al. 1948, p. b. 757, Dopis Moše Medine iz Jerusalima, Albertu Vajsu, 19. avgust 1949. 
Medina was under investigation at the time when he applied for emigration. ${ }^{64}$ Items deposited with the State Security Service could not be released in time for him to take them to Israel at that time. After Albert Vajs insisting, the belongings of Moše Medina were released and sent to Israel aboard the "Užice", a ship that in September of 1949 left Yugoslavia with the luggage of second wave migrants. ${ }^{65}$

Speaking towards the diversity of questions with which individuals approached Albert Vajs is the example of a migrant by the name of Altarac. ${ }^{66}$ Mid 1949 Albert Vajs was asked to help the aforementioned Altarac transfer money to his brother who had left Yugoslavia with the first wave of organized migration. It seems Vajs had participated in similar transfers before, as the documents at hand tell of numerous similar requests made by the same people up until that point in time. This time Albert Vajs mediated in the purchase of one hundred and forty gold English pounds, ${ }^{67}$ which were sent to Israel by means of the National Bank (Narodna banka) in Belgrade. ${ }^{68}$

In an attempt to bypass the structure introduced to the migration process, individuals were mainly trying to contact Albert Vajs. Few of them were, however, in a position to address the President of the Federation directly. Therefore, requests similar to those addressed to Albert Vajs were also sent to other high-ranking officials of the Jewish community in Yugoslavia. ${ }^{69}$ A relatively large number of them was directed at Naftali Bata Gedalja, secretary of the Federation of Jewish religious communities of Yugoslavia.

In January of 1949, Polak Bela from Čačak addressed the Federation inquiring about the possibility of leaving Yugoslavia with the following wave of organized emigration. ${ }^{70}$ In his letter, he states having visited the secretary of the Federation, Naftali Gedalja when the first wave of organized emigration was already concluded. In this instance he complained about the community in Belgrade, of which he was a member, not informing him about the first wave in due time. This was, as he stated, the main reason he didn't leave the country at that time. ${ }^{71}$ This

${ }^{64}$ AJHM, Al. 1948, p. b. 757, Dopis SJVOJ, Leni Vukajlović iz Beograda, 8. avgust 1949, Pov. br. $2750 / 49$.

${ }^{65}$ AJHM, Al. 1948, p. b. 757, Pismo Alberta Vajsa, Moše Medini iz Jerusalima, 7. septembar 1949.

${ }^{66}$ AJHM, Al. 1948-1952, p. b. 744, Pismo, 9. jun 1949.

${ }^{67}$ After proclaiming independence, up until 1952, the official currency used by Israel was the socalled Palestine pound. This currency was introduced in 1927 by British mandate authorities with a value equivalent to that of the pound sterling. The Palestine pound was used until May $14^{\text {th }} 1948$. The Palestine pound was up until 1949 used by Transjordania too. See in more detail: Sheemati Mitter, A History of Money in Palestine: From the 1900s to the Present, https://dash.harvard.edu/handle/1/12269876 (accessed 21. 1. 2018).

${ }^{68}$ AJHM, Al. 1948-1952, p. b. 744, Pismo, 9. jun 1949.

${ }^{69}$ The case of Leopold Švarc is especially interesting. Attempting to secure his own and the position of his wife within the second wave of organized emigration, Švarc contacted the president of the Jewish community in Belgrade, David Alkalaj, the secretary of the Federation, Naftali Gedalja; and finally Albert Vajs himself, AJHM, Al. 1948, p. b. 757, Dopis Leopolda Švarca, SJVOJ-u, 8. jun 1949, Pov. br. 1892/49.

${ }^{70}$ AJHM, Al. 1948, p. b. 757, Pismo Polak Bele, SJVOJ-u, 25. januar 1949, Pov. br. 176/49.

71 „I would have probably already been in Israel by now, had I known about the previous wave of organized emigration“, Ibid. 
particular case, however, shows that not every attempt made by an individual to somehow modify the organized migration process was motivated by subjective needs. An unexpected turn of events was just a good a cause as any.

The secretary of the Federation of Jewish religious communities of Yugoslavia was approached mid-March 1951 by Bela Buhvald, acting on behalf of Martin Vajs. ${ }^{72}$ Buhvald was attempting to define the conditions under which Vajs could leave the country by directly communicating with Naftali Gedalja. He insisted on having contacted Gedalja with the same question on numerous occasions before that. In the same sense, Rafael Papo insisted on Gedalja giving him a phone call as soon as the permission for his son to leave the country was ready. ${ }^{73}$

\section{Conclusion}

The organizational framework of mass emigration from Yugoslavia to Israel was defined by the Federation of Jewish religious communities in cooperation with relevant state authorities. For decisions reached at the highest level to be implemented, a specific structure was introduced into the community, based on a division of jurisdictions and precisely defining the interaction of individual participants. In August of 1948, the Central emigration commission was constituted with the Federation of Jewish religious communities in Belgrade. This institution was to play the key role in preparing mass emigration. Its primary function was mediating between state authorities and the Jewish community. Directly beneath the Central commission were a number of Regional commissions, formed with the most numerous local communities in Yugoslavia. Each Regional commission was in charge of a certain number of Local commissions, functioning with individual communities. Finally, every Local commission was in charge of migrants coming from its territory. This basic structure remained unchanged until the end of organized emigration from Yugoslavia to Israel.

In preparing each individual wave of migration the Central commission was to communicate relevant information to Regional commissions, which would then pass these on to Local Commissions. Commissions formed with local communities were then in charge of informing their members about the emigration. The same rule was applied when communication was directed the other way. Individuals were directed at the commission functioning with the local community. In case of such a need arising, these would then pass the inquiry on to Regional Commissions. The Federation, that is the Central emigration commission, was contacted only if no lower instance was able to handle the problem at hand. State authorities could only be approached by Federation officials.

The proposed structure of organized emigration could, at the best of times, only be implemented half way. Information was reaching individuals that had applied for leaving the country with no problems or serious difficulties. Communication going the other way, however, was a different story altogether.

\footnotetext{
72 AJHM, Al. 1949-1951, p. b. 837, Dopis Buhvald Bele, SJVOJ-u, 19. mart 1951, Pov. br. 548/51.

${ }^{73}$ AJHM, Al. 1948, p. b. 753, Dopis Rafaela Papa, Bati Gedalji, 25. maj 1949.
} 
The proposed model proved to be completely incompatible with the way in which local communities and individual émigrés understood their own position in the process. Local communities perceived themselves as being the only true representatives of migrants coming out of their jurisdiction. Therefore, as a rule, they ignored Regional communities, approaching the Federation directly. Individuals acted accordingly, trying to reach out to high ranking officials of the Jewish community whenever they were confronted with a problem.

Compromising or completely ignoring the proposed structure of mass emigration from Yugoslavia to Israel was, for the most part, a consequence of the specific internal dynamic and compactness of the Jewish community. Lacking knowledge on how the internal structure of the process was set up, as well as lacking trust in some of the institutions (primarily Regional commissions), communication within the Jewish community basically reverted to the traditional interaction of individuals, local communities and the Federation. Individual participants in the process were, however, continuously attempting to bypass even this traditional framework, by directly communicating with high ranking Federation officials. Although there was an official structure introduced to it, it was the unofficial interaction of different participants that for the most part defined organized Jewish migration from Yugoslavia to Israel.

\section{REFERENCES}

- Alfassi, Itzhak. Immigration and Settlement. Jerusalem: Ketter Books, 1973.

- Crisp Richard, and Turner Rhiannon. Essential Social Psychology. London: Sage, 2007.

- Gahagan, Judy. Interpersonal and Group Behaviour. London: Methuen, 1975.

- Grünfelder, Anna. „Aufgeschobene Vernichtung. Jüdische Emigration nach Jugoslawien (1933-1938-1945)“. Südosteuropaforschung, nr. 71, (2012), 233-284.

- Gruenfelder, Anna Maria. „Nepoželjni gosti. Židovske izbeglice u Jugoslaviji (1938-1945)“. Zbornik Jevrejskog istorijskog muzeja, br. 10, (2015), 303-362.

- Ivanković, Mladenka. Jevreji u Jugoslaviji (1944-1952), Kraj ili novi početak. Beograd: Institut za noviju istoriju Srbije, 2009.

- Ivanković, Mladenka. „Odlazak jevrejskih izbeglica - žrtava Holokausta iz evropskih zemalja za Palestinu preko teritorije Jugoslavije 1946/7. godine“. Tokovi istorije, br. 3, (2006), 141-153.

- Kerkkänen, Ari. Yugoslav Jewry: Aspects of post-World War II and postYugoslav developments. Helsinki: Finnish Oriental Society, 2001.

- Koljanin, Milan. Jevreji i antisemitizam u Kraljevini Jugoslaviji 1918-1941. Beograd: Institut za savremenu istoriju, 2008.

- Law of Return 5710-1950 (05 Jul 1950), http://www.mfa.gov.il/mfa/mfaarchive/1950-1959/pages/law\%20of\%20return\%205710-1950.aspx, (accessed 25. 4. 2018)

- Mitter, Sheemati, A History of Money in Palestine: From the 1900s to the Present, https://dash.harvard.edu/handle/1/12269876, (accessed 21. 1. 2018) 
- Neumann, Shoshanna. Aliyah to Israel: Immigration under Conditions of Adversity. Bonn: Forschungsinstitut zur Zukunft der Arbeit, 1999.

- Perić Marko, i Srećko Stanić. „Jevreji Beograda u popisima stanovništva XIX i XX veka“. Zbornik Jevrejskog istorijskog muzeja, br. 6, (1992), 294-295.

- Port, Andrew. „History from Below, the History of Everyday Life, and Microhistory“. In: International Encyclopedia of the Social \& Behavioral Sciences, 2nd edition, Volume 11, 108-113. Oxford: Pergamon Press, 2015.

- Radovanović, Milan. „Cionizam i pragmatizam - Zašto su se jugoslovenski Jevreji iselili u Izrael? (1948-1952)“. Beogradski istorijski glasnik, br. 6, (2015), 215-249.

- Radovanović, Milan R. „Iseljavanje Jevreja iz Jugoslavije u Izrael (19481952)“. Doktorska disertacija, Univerzitet u Beogradu, Filozofski fakultet, Odeljenje za istoriju, 2015.

- Radovanović, Milan. „Organizovana emigracija kapitala - Zbirni račun repatriraca u Izrael (1948-1952)“. Arhiv, br. 1-2, (2017), 164-184.

- Radovanović, Milan. „Pojedini ekonomski aspekti organizovanog iseljavanja jugoslovenskih Jevreja u Izrael 1948/49. godine“. Godišnjak za društvenu istoriju, br. 3, (2011), 81-102.

- Radovanović, Milan. „Pojedini statistički aspekti organizovanog iseljavanja Jevreja iz Jugoslavije u Izrael (1948-1952)“. Godišnjak za društvenu istoriju, br. 2, (2015), 53-81.

- Radovanović, Milan. „The State, the Organization and the Individual - A three-level Approach to Migration". In: Where is Civil Society in Central Europe heading to?. Edited by Inocent-Mária Staniszlo et al., 169-187. Prešov: Michal Vaško Press, 2015.

- Rafailović, Aleksandar. „Albert Vajs“. U: Znameniti Jevreji Srbije, 50-51. Beograd: Savez jevrejskih opština Srbije, 2011.

- Ristović, Milan. „Jugoslavija i jevrejske izbeglice 1938-1941“. Istorija 20. veka, br. 1, (1996), 21-43.

- Ristović, Milan. „Turisti pod sumnjom (o jednom vidu politike Kraljevine Jugoslavije prema jevrejskim izbeglicama 1938-1941. godine)“. U: Kladovo transport: Zbornik radova sa okruglog stola. Urednik Andrej Mitrović, 170189. Beograd: Jevrejski istorijski muzej, 2006.

- Ristović, Milan. "Unsere und fremde Juden. Zum Problem der Jüdischen Flüchtlinge in Jugoslawien 1938-1941”. In: Zwischen grossen Erwartungen und bösem Erwachen. Juden, Politik und Antisemitismus in Ost- und Südosteuropa 1918-1945. Herausgegeben von Dittmar Dahlmann und Anke Hilbrenner, 191-216. Paderborn - München: Schöningh, 2007.

- Rot, Nikola. Psihologija grupa. Izabrana dela - tom IV. Beograd: Zavod za izdavanje udžbenika, 2010.

- “The British White Paper of 1939”, http://avalon.law.yale.edu/20th_century/ brwh1939.asp (accessed 23. 1. 2018).

- Vajs, Albert. „Jevreji u novoj Jugoslaviji“, Jevrejski almanah, (1954), 125-126. 
MILAN RADOVANOVIĆ, PhD, Historian

Belgrade, Republic of Serbia

mradowanovic@gmail.com

\section{THE INTERNAL FRAMEWORK OF ORGANIZED JEWISH MIGRATION FROM YUGOSLAVIA TO ISRAEL (1948-1952)}

\section{Summary}

In the process of taking necessary preparations for mass Jewish emigration to Israel, during which almost 8,000 people left Yugoslavia, executives of the Federation of Jewish religious communities of Yugoslavia decided on defining a specific structure within the community to deal with two basic tasks communicating information relevant to the migration to all of the participating sides and dealing with problems potentially arising from the process. This was to be achieved through a network of Emigration Commissions. The Central Emigration Commission, established in Belgrade and consisting of Federation Executive Board Members, was in charge of coordinating the migration process on a grand scale. Regional Emigration Commissions were formed with larger Jewish communities, each of them responsible for organizing the migration in a number of communities under their jurisdiction. Finally, local Emigration Commissions were founded with each community taking part in the migration. In theory, the interaction of these Commissions was limited by a very strict hierarchy. While top to bottom communication honoured the proposed model for the most part, passing information in the opposite direction proved to be much more of a challenge. Traditional dynamics within the Jewish community proved a much more significant influence than the proposed internal hierarchy. It was due to this what interpersonal relations ended up playing a far more significant role than did the network of Emigration Commissions. This paper examines how the organized emigration process was influenced by the proposed hierarchy, how the proposed distribution of different duties amongst the various levels of Emigration Commissions functioned when applied to real problems and what led to this internal framework finally failing. Relevant documents, used in writing this paper are held at the Archives of the Jewish Historical Museum in Belgrade.

KEYWORDS: migration, structure, Jews, Yugoslavia, Israel 